\title{
4+4+4 EĞİTİM SİSTEMİNİN AİLE VE SOSYAL POLİTIKALAR BAKANLIĞINA YANSIMALARI ${ }^{1}$
}

Davut ELMACI ${ }^{2}$

Atıf/C: Elmacı, Davut (2017). 4+4+4 Eğitim Sisteminin Aile ve Sosyal Politikalar Bakanlığına Yansımaları, Hitit Üniversitesi Sosyal Bilimler Enstitüsü Dergisi, Yıl 10, Sayı 1, Haziran 2017, ss. 279-292

Özet: Kamuoyunda 4+4+4 olarak bilinen 12 yillı zorunlu eğitim düzenlemesi, Aile ve Sosyal Politikalar Bakanlığını da etkilemiştir. 12 yıllık zorunlu eğitimle birlikte Aile ve Sosyal Politikalar Bakanlığı Çocuk Hizmetleri Genel Müdürlüğüne bağlı koruma altındaki çocuklara hizmet veren sosyal hizmet kuruluşlarinın yapilanmalarında değişiklikler olmuştur. Koruma altındaki çocuklara hizmet veren bu kuruluşlarda yapılanma daha önce 0-6 yaş, 7-12 yaş ve 13-18 yaş şeklindeyken 12 yıllık zorunlu eğitimle birlikte bu yaş sinırları 4+4+4 eğitim sistemine uygun olacak şekilde düzenlenmeye çalışılmiştır. Bunun dişında çocukların kuruluşlardan ayrılışı, şartlı eğitim yardımı programının uygulanması ve personelin sorumlulukları gibi konularda da Aile ve Sosyal Politikalar Bakanlığı yeni eğitim sisteminden etkilenmiştir.

Anahtar Kelimeler: 4+4+4 Eğitim Sistemi, Aile ve Sosyal Politikalar Bakanlığı, Koruma Altındaki Çocuklar

Makale Gelis Tarihi: 04. 04. 2017/ Makale Kabul Tarihi: 21.06.2017

1 Bu makale, 4-6 Eylül 2014 tarihlerinde Kocaeli’nde düzenlenen 23. Ulusal Eğitim Bilimleri Kurultayında sözlü olarak sunulan aynı başlıklı bildirinin geliştirilmiş halidir.

2 Yrd. Doç. Dr., Amasya Üniversitesi, Eğitim Fakültesi, e-posta: davut.elmaci@amasya.edu.tr 


\section{Reflection of The 4+4+4 Education System to Ministry of Family And Social Policies}

Citation/(-): Elmact, Davut (2017). Reflection of the 4+4+4 Education System to Ministry Of Family And Social Policies, Hitit University Journal of Social Sciences Institute, Year 10, Issue 1, June 2017, pp. 279-292

Abstract: 12-year compulsory education arrangement known as 4+4+4 in public also affected Ministry of Family and Social Policies. With 12 year compulsory education, there have been changes in the structuring of social service organizations which affiliate to Ministry of Family and Social Policies and provide services to children in care. In these organizations which provide services to children in care, organizational structuring was 0-6 years old, 7-12 years old, and 13-18 years old before, with 12 years compulsory education these age limit tried to be apropriate to 4+4+4 education system. Apart from these, on issues such as leaving from care, implementing of conditional cash transfer on education and responsobilities of staff, Ministry of Family and Social Policies had been affected by new education system.

Keywords: 4+4+4 Education System, Ministry of Family and Social Policies, Children in Care.

\section{GÍRIŞ}

Kamuoyunda 4+4+4 olarak bilinen ve zorunlu eğitimi 12 yıla çıkaran düzenleme ile eğitim sistemimizde büyük değişiklikler yapılmıştır. İlköğretime başlama yaşının erkene alınması, ders çizelgesi ve öğretim programlarının değişimi, ilköğretimin ilkokul ve ortaokul şeklinde ayrılması, imam hatip ortaokullarının yeniden açılması, ortaöğretimin zorunlu eğitim kapsamına alınması bu kapsamda yapılan önemli değişikliklerdir. Bu düzenlemelerle birlikte öğrenciler artık 12 yıllık zorunlu eğitim süresini tamamladıklarında diploma alabileceklerdir. Bu değişikliklerin olumlu ya da olumsuz olduğu konusunda ise toplumda bir birliktelik bulunmamakta, yapilan düzenlemelerin artı ve eksileri tartışılmaya devam edilmektedir (Milli Eğitim Bakanlı̆̆1, 2012; Eğitim-İş, 2012; Çelik, Boz, Gümüş ve Taştan, Tarihsiz; Eğitim Reformu Girişimi, Tarihsiz). Tartışmalar devam etmekle birlikte eğitim sistemimizdeki bu önemli değişiklik Milli Eğitim Bakanlığı dışındaki kurumları da etkilemiştir. Örneğin, Hastane İlköğretim Okulları kapatılarak zorunlu öğrenim çağında olup sağlık kuruluşlarında yatarak tedavi gören öğrencilerin hastaneler bünyesinde açılacak olan Hastane Sinıfinda 
öğrenimlerini sürdürmeleri konusunda yeni bir düzenleme yapılmıştır (Milli Eğitim Bakanlığı, 16/08/2012 tarihli ve 3284 sayılı yazı).

Yeni eğitim sisteminden etkilenen kurumlardan birisi de Aile ve Sosyal Politikalar Bakanlığı (ASPB)'dır. Aile ve Sosyal Politikalar Bakanlığı, sosyal devlet olmanın bir gereği olarak kurulmuştur ve tüm risk grubu insanların yaşamlarını organize ederek ve korunmaya ihtiyacı olan kesimleri sahiplenerek hizmetlerini sunmaya çalışan en büyük ve en önemli bakanlıklardan birisidir. Daha önceden sadece korunmaya ve yardıma ihtiyaç duyan insanlara hizmet vermek ön plandayken, Aile ve Sosyal Politikalar Bakanlığının kurulmasıyla birlikte tüm risk grubundaki insanlar ele alınarak bunların üretken ve sağlıklı bir birey olarak yeniden toplumsal hayata katılmalarını sağlamak daha önemli hale gelmiştir (ASPB, 2012).

\section{AİLE VE SOSYAL POLİTİKALAR BAKANLIĞININ GÖREVLERİ}

Aile ve Sosyal Politikalar Bakanlığ1 (ASPB), 03.06.2011 tarihli ve 633 sayılı Kanun Hükmünde Kararname ile kurulmuştur. Aile ve Sosyal Politikalar Bakanlığının kurulmasıyla birlikte Sosyal Hizmetler ve Çocuk Esirgeme Kurumu, Aile ve Sosyal Araştırmalar Genel Müdürlüğü, Sosyal Yardımlaşma ve Dayanışma Genel Müdürlüğü, Kadının Statüsü Genel Müdürlüğü ve Primsiz Ödemeler Genel Müdürlüğünün faaliyetleri sonlandırılmış ve bu kurumlarca yapılan faaliyetler Aile ve Sosyal Politikalar Bakanlığına devredilmiştir (ASPB, 2012).

ASPB'nin kuruluş, görev, yetki ve sorumluluklarını düzenleyen 08.06.2011 tarihli ve 27958 say1l Resmi Gazetede yayınlanan 633 sayıl1 Kanun Hükmünde Kararnamede (KHK) Bakanlığın görevleri belirtilmiştir. Buna göre sosyal hizmetler ve yardımlara ilişkin ulusal düzeyde politikaların ve stratejilerin geliştirilmesi, uygulanması, izlenmesi, bu politika ve stratejilerin yeni hizmet ihtiyaçlarına göre güncellenerek geliştirilmesi Bakanlığın öncelikli görevleri arasındadır. ASPB'nin 633 sayılı KHK'da belirtilen görevleri aşağıdaki gibi açıklanabilir:

ASPB'nin önemli görevlerinden birisi sosyal ve kültürel dokudaki aşınmalara karşı aile yapısının ve değerlerinin korunarak gelecek nesillere sağlıklı biçimde aktarılmasının sağlanmasıdır. Bunun için Bakanlığın ulusal politika ve stratejilerin belirlenmesini koordine etmesi, aile bütünlüğünün korunması ve aile refahının artırılmasına yönelik sosyal hizmet ve yardım faaliyetlerini yürütmesi, bu alanda ilgili kamu kurum ve kuruluşları ile gönüllü kuruluşlar 
arasında işbirliği ve koordinasyonu sağlaması gerekmektedir. Diğer yandan Bakanlığın aile bütünlüğünün korunması, parçalanmış ailelerin korunmaya, yardıma ve bakıma ihtiyacı olan fertleriyle çocuklarına her türlü maddi, manevi ve sosyal desteğin sağlaması için gerekli planlamaları yapması gereklidir.

ASPB'nin sunduğu temel hizmetlerden birisi de kadına yönelik hizmetlerdir. Kadına karşı ayrımcılığın önlenmesi, kadının insan haklarının korunması ve geliştirilmesi, kadınların toplumsal hayatın tüm alanlarında hak, fırsat ve olanaklardan eşit biçimde yararlanmalarının sağlanması gerekmektedir. Engelli ve yaşl1lara yönelik hizmetler de ASPB'nin önemli hizmetleri arasındadır. Engellilerin ve yaşlıların her türlü engel, ihmal ve dışlanmaya karş1 ayrımcılığa uğramadan toplumsal hayata etkin bir şekilde katılımlarının sağlanması önemlidir.

Daha önce İçişleri Bakanlığı bünyesinde yerine getirilen şehit yakınları ve gazilere yönelik hizmetler 633 sayılı KHK ile ASPB'ye devredilmiştir. Şehitlerimizin hatıralarının yaşatılması, şehit yakınları ile gazilerin her türlü mağduriyetten ve mahrumiyetten korunması Bakanlığın görevleri arasındadır. Toplumun sosyal yardım ve korumaya ihtiyaç duyan kesimlerine yönelik yardım faaliyetlerinin düzenli ve etkin biçimde yürütmesi de Bakanlığın görevleri arasındadır. ASPB'nin en önemli hizmet alanının çocuklara yönelik hizmetler olduğu söylenebilir. Çocukların her türlü ihmal ve istismardan korunması ve sağlıklı gelissimlerinin güvence altına alınması Bakanlığın en önemli görevlerindendir. ASPB'nin temel politikaları çocuğun öncelikle aile içerisinde desteklenmesini hedeflemektedir. Bunun için ailenin eğitim, danışmanlık ve sosyal yardımlarla güçlendirilmesi önemli görülmektedir. Bakanlığın korunmaya, bakıma ve yardıma ihtiyacı olan çocuk, kadın, engelli ve yaşlıları tespit etmesi, bunların korunması, bakımı, yetiştirilmesi ve rehabilitasyonlarını sağlamak üzere gerekli hizmetleri yürütmesi, bu hizmetler için gündüzlü ve yatılı sosyal hizmet kuruluşlarını kurması ve işletmesi gerekmektedir.

Diğer yandan kamu kurum ve kuruluşları, gönüllü kuruluşlar ve gerçek ve tüzel kişiler tarafından yürütülen sosyal hizmetlere ve yardımlara ilişkin ilke, usûl ve standartların belirlenmesi, bu alanda faaliyet gösteren kurum ve kuruluşların taşıması zorunlu olan nitelikleri ve bunlara rehberlik edecek programların geliştirilmesi de Bakanlık görevleri arasındadır. Bunun dişında kamu kurum ve kuruluşları, gönüllü kuruluşlar ile gerçek ve tüzel kişiler 
tarafından yürütülen sosyal hizmet ve yardım faaliyetlerinin, belirlenen ilke, usûl ve standartlar çerçevesinde denetiminin yapılması gerekmektedir.

ASPB'nin aynı zamanda sosyal hizmet ve yardım faaliyetleriyle bunlardan yararlananlara ilişkin bilgileri merkezi bir sistemde oluşturulacak veri tabanı aracılığıyla işlemesi, kontrol etmesi, izlemesi ve geliştirilecek politika, strateji ve önlemler bağlamında değerlendirmesi de gerekmektedir. Sosyal hizmetler ve yardımlar alanındaki uluslararası gelişmelerin ve faaliyetleri izlenmesi, bunlara katkı vermek ve yürütülecek çalışmalarda yararlanmak üzere değerlendirilmesi bu alanda taraf olunan uluslararası sözlessme ve anlaşmaların ulusal düzeyde uygulanmasının sağlanması de Bakanlık görevleri arasındadır.

Görüldüğü gibi, Aile ve Sosyal Politikalar Bakanlığının çocuk, engelli, kadın, yaşlı gibi çok geniş gruplara yönelik hizmetleri bulunmakta ve aynı zamanda Bakanlıktan bu gruplara yönelik hizmetlere ilişkin politikalar geliştirilmesi beklenmektedir. Bu kapsamda Bakanlığın ulusal politika ve stratejilerin belirlenmesini koordine etmesi, dezavantajlı ve ihtiyaç sahibi gruplara yönelik sosyal hizmet ve yardım faaliyetlerini yürütmesi, bu alanda ilgili kamu kurum ve kuruluşları ile gönüllü kuruluşlar arasında işbirliği ve koordinasyonu sağlaması beklenmektedir.

Çocuklara yönelik hizmetler ASPB'nin en önemli hizmet gruplarından birisidir. Çocuklara yönelik hizmetleri dolayısıyla Aile ve Sosyal Politikalar Bakanlığının Milli Eğitim Bakanlığıyla yakın bir ilişki içinde olması kaçınılmaz bir durumdur. Aile ve Sosyal Politikalar Bakanlığında çocuklara yönelik hizmetlerden esas sorumlu birim Çocuk Hizmetleri Genel Müdürlüğüdür. Çocuk Hizmetleri Genel Müdürlüğünün görevleri 633 sayılı KHK'de şu şekilde belirtilmiştir:

a) Bakanlığın çocuklara yönelik koruyucu, önleyici, eğitici, geliştirici, rehberlik ve rehabilite edici sosyal hizmet faaliyetlerinin yürütülmesi ve koordine edilmesi,

b) Çocuklara yönelik sosyal hizmetler konusunda politika ve stratejiler belirlenmesine ilişkin çalışmaların koordine edilmesi, belirlenen politika ve stratejilerin uygulanması, uygulamaların izlenmesi ve değerlendirilmesi,

c) Kamu kurum ve kuruluşları, gönüllü kuruluşlar ile gerçek ve tüzel kişilerce çocuklara yönelik yürütülen sosyal hizmetlere ilişkin ilke, usûl ve standartların belirlenmesi ve bunlara uyulmasının sağlanması, 
c) Çocukların her türlü ihmal ve istismardan korunması ve sağlıklı gelişimi için gerekli önleyici ve koruyucu mekanizmaların oluşturulması ve uygulamaya konulmasi,

d) Geçici ya da sürekli olarak aile ortamından mahrum kalan veya yüksek yararı ailesinin yanında bulunmamayı gerektiren çocuklara özel bakım ve koruma hizmeti sunulmas1,

e) Özel surette korunması gereken çocuklara yönelik hizmetlerin, habersiz denetimleri de kapsayacak ssekilde yerinde denetlenmesi, tespit edilen aksaklıklara ve yetersizliklere karşı gerekli önlemlerin alınması,

f) Özel surette korunması gereken çocuklara en nitelikli hizmetin verilebilmesini amacıyla fiziki altyap1, nitelikli personel yetiştirilmesi ve istihdamı gibi hususlarda gerekli önlemlerin alınması,

g) Özel surette korunması gereken çocukların ilgili mevzuat uyarınca işe yerleştirilmesi işlemlerinde koordinasyonun sağlanması,

ğ) Özel surette korunması gereken çocuklara yönelik hizmetler konusunda kamu kurum ve kuruluşlarıyla gönüllü kuruluşlar arasında işbirliği ve koordinasyonun sağlanması, bu alandaki gönüllü girişimleri teşvik edici mekanizmaların geliştirilmesi ve uygulanması,

h) Özel surette korunması gereken çocuklar sorununda toplumsal duyarlılığ ve dayanışmayı güçlendirici faaliyet, proje ve kampanyalar düzenlenmesi,

1) Evlat edindirme ve koruyucu aile hizmetlerinin koordine edilmesi,

i) 5395 sayılı Çocuk Koruma Kanununda belirlenen tedbirlerin yürütülmesi ve koordinasyonunun sağlanmas1,

Çocuk Hizmetleri Genel Müdürlüğünün görevleri incelendiğinde çocuklara yönelik koruyucu ve önleyici hizmetler ile korunması gereken çocukların bakım ve yetiştirilmelerinin bu Genel Müdürlüğün temel görevleri arasında olduğu görülmektedir. Çocukların yaşamlarının önemli bir bölümünün okullarda geçmesi, 5395 sayılı Çocuk Koruma Kanununda çocukların korunmasıyla ilgili gerek Aile ve Sosyal Politikalar Bakanlığına gerekse Milli Eğitim Bakanlığına görevler verilmesi, Aile ve Sosyal Politikalar Bakanlığı tarafından bakım ve yetiştirilmeleri sağlanan koruma altındaki çocukların Milli Eğitim Bakanlığına yönelik okullarda öğrenim görmeleri gibi nedenlerle Milli Eğitim Bakanlığında meydana gelen bir değişikliğin Aile ve Sosyal Politikalar Bakanlığını da etkilemesi olağan bir durumdur. 


\section{YENI EĞİTİM SİSTEMİNíN AİLE VE SOSYAL POLİTİKALAR BAKANLIĞINA ETKILERI}

4+4+4 eğitim sistemi, Milli Eğitim Bakanlığında meydana gelen ve Aile ve Sosyal politikalar Bakanlığını da etkileyen önemli bir düzenlemedir. Yeni eğitim sistemiyle birlikte Aile ve Sosyal Politikalar Bakanlığında meydana gelen bu değişikliklerin esas olarak çocuk koruma kuruluşlarının yapılandırılması, çocukların kuruluşlardan ayrılışı, şartlı eğitim yardımı programı ve personelin sorumlulukları olmak üzere dört başlık altında toplanması mümkündür. 4+4+4 eğitim sisteminin Aile ve Sosyal Politikalar Bakanlığına yansımalarının bir sonucu olan bu değişiklikler aşağıda açıklanmaktadır.

\section{A. Çocuk Koruma Kuruluşlarının Yapılandırılması}

Aile ve Sosyal Politikalar Bakanlığı, korunma ihtiyacı olan ve koruma altına alınan çocuklara çocuk koruma kuruluşları aracılığıyla yatılı sosyal hizmetler sunmaktadır. Aile ve Sosyal Politikalar Bakanlığında korunma altındaki çocuklara yönelik başlıca yatılı sosyal hizmet kuruluşları; Çocuk Yuvaları, Yetiştirme Yurtları, Sevgi Evleri, Çocuk Evleri, Koruma Bakım ve Rehabilitasyon Merkezleri, Bakım ve Sosyal Rehabilitasyon Merkezleridir. ASPB Çocuk Hizmetleri Genel Müdürlüğünün 2014 yılı Mayıs ayı verilerine göre bu kuruluşlarda 12.665 çocuğa hizmet verilmektedir. Koruyucu aile yanında bakılan çocuk sayısı da 3.656'dır (Çocuk Hizmetleri Genel Müdürlüğü, 2014).

Aile ve Sosyal Politikalar Bakanlığı Çocuk Hizmetleri Genel Müdürlüğünün 24/08/2012 tarihli 1233 say1l ve 28/082012 tarihli 2581 sayılı yazıları ile Bakanlığa bağlı kuruluşların 6287 sayılı kanunda yer alan düzenlemeye paralel yapılandırılması talimatı verilmiştir. Daha önce çocuk koruma kuruluşlarında yapılanma 0-6 yaş çocuk yuvaları, 7-12 yaş çocuk yuvaları ve 13-18 yaş yetiştirme yurtları şeklindeyken yeni eğitim sistemiyle birlikte bu yaş grupları değişmiştir. Aile ve Sosyal Politikalar Bakanlığının 28.08.2012 tarih ve 2581 sayılı "12 Yıllık Zorunlu Eğitim Kapsamında Kuruluşların Yapılandırılması” konulu yazılarında çocukların yaş, cinsiyet, eğitim ve gelişimsel özellikleri dikkate alınarak; 0-6 yaş kuruluşların 0-5 yaş şeklinde, 7-12 yaş kuruluşların 6-9 yaş ve 10-13 yaş şeklinde, 13-18 yaş mevcut kuruluşların ise 14-15 yaş ve 16-18 yaş şeklinde yapılandırılması istenmiştir. Diğer yandan, 10-13 yaş erkek çocukların müstakil bir kuruluşa 
yerleştirilmesi ve buna göre kuruluş planlamasının yapılması gerektiği belirtilmiştir.

0-6 yaş grubunda olup, sağlık raporuna istinaden ilkokula başlaması uygun görülmeyen çocuklar ise mevcut kuruluşlarında kalmaya devam edecek, ilkokula başlatılanların öncelikle çocuk evlerine yerleştirilmesi, bunun mümkün olmaması halinde ise durumlarına uygun bir kuruluşa nakilleri yapılacaktır. 0-12 yaş ve 12 yaş üzeri çocuklara yönelik hizmet veren kuruluşlar; çocukların gelişimlerine ve yeni eğitim öğretim sistemine $(4+4+4)$ uygun olarak yapılandırılacak, yerleşim planı buna göre oluşturulacak, ihtiyaç halinde çocukların uygun kuruluşlara nakillerinin yapılacak ve 12 yaş ve üzeri çocukların çocuk evlerine yerleştirilmesine öncelik verilecektir (ASPB, 28.08.2012 tarih ve 2581 sayıl1 yaz1).

Çocuk koruma kuruluşlarında bu düzenlemeler yapılırken aynı zamanda çocukların okulöncesi, ilkokul, ortaokul ve liseye kayıtlarıyla ilgili iş ve işlemlerin gerçekleştirilmesi, bu çerçevede kaydı yapılmayan çocuk bırakılmaması, 60-66 ay aralığında bulunan çocukların yaş ve gelişim özellikleri ilkokula başlamak için uygun bulunanların ilkokula kayıt işlemlerinin gerçekleştirilmesi, 60-66 ay ve üzeri çocuklardan, bedenen ve zihnen okula hazır olmadığı sağlık kurumlarından verilen raporla tespit edilenlerin okul öncesi eğitime devamlarının sağlanması konularında da gerekli hassasiyetin gösterilmesi istenmiştir (ASPB, 28.08.2012 tarih ve 2581 say1l1 yaz1).

\section{B. Çocukların Kuruluşlardan Ayrılıșı}

Koruma altındaki çocukların ilgili mahkemelerce verilen korunma kararları normal olarak çocuk 18 yaşına geldiğinde sona ermektedir. Ancak bu karar, korunma kararına neden olan şartların ortadan kalkması halinde kurum yetkililerinin önerisi üzerine mahkemece çocuk reşit olmadan önce kaldırılabileceği gibi reşit olduktan sonra da çocuğun rızası alınmak şartıyla korunma kararının devamı hususunda karar verilebilir. 18 yaşını tamamlamış olan korunmaya ihtiyacı olan çocuklardan ortaöğrenime devam edenlerin 20 yaşına kadar, yükseköğrenime devam edenlerin ise 25 yaşına kadar korunma kararları uzatılabilir. Öğrenime devam etmeyen 18 yaşını doldurmuş çocukların bir iş veya meslek sahibi edilerek kendi kendilerine yeterli olabilmelerinin sağlanması amacıyla 20 yaşına kadar korunma kararları uzatılabilir (2828 Sayılı Kanun, Madde 24). 
4+4+4 eğitim sistemiyle zorunlu eğitim 12 yıla çıktığından çocukların öğrenim süreleri de uzamıştır. Böyle olunca da koruma altındaki çocukların büyük çoğunluğu normal olarak 18 yaşından önce zorunlu eğitimi tamamlayamamış olmaktadır. Bunun sonucu olarak da çocuğun lise öğrenimini bitirinceye kadar ya korunma kararının uzatılması amacıyla ilgili mahkemeden korunma kararının uzatılması için karar alınması gerekmekte ya da çocuk lise öğrenimini korunma kararı kaldırıldıktan sonra kurum dışında kendisi tamamlamaktadır. Çocuk koruma kuruluşları genellikle çocuklar 18 yaşına geldiğinde korunma kararlarının kaldırılması eğiliminde olmaktadır. Ancak kuruluşta uyum sorunu yaşamayan ve eğitiminde başarılı olan çocuklar ile kuruluştan ayrıldıklarında çok güç durumda kalacakları düşünülen çocukların korunma kararlarının uzatılmasının daha tercih edilen bir durum olduğu söylenebilir.

Diğer yandan koruma altındaki çocuklar reşit olup korunma kararı kaldırılarak kurumdan ayrıldıklarında kendilerinin kamu kurum ve kuruluşlarında istihdam edilebilmeleri için bir Form-A belgesinin düzenlenmesi gereklidir. Kamu kurum ve kuruluşları tarafından hangi statüde olursa olsun serbest kadro ve pozisyonları toplamının binde birinin, koruma altında yetişen çocuklar için ayrılması gerekmekte ve her yıl belirtilen oranda koruma altında yetissen gencin kamu kurum ve kurulusslarında istihdam edilmesi sağlanmaktadır (2828 Sayılı Kanun, Ek madde / 1a). İşte Form-A belgesi, koruma altında yetişen gençlerin bu haktan yararlanabilmeleri için kurumca doldurulması gerekli bir belgedir. Daha önceleri Form-A belgesi ilkokul mezunu da olsa reşit olduğunda her çocuk için doldurulabiliyorken, yeni düzenlemeyle zorunlu eğitim 12 yıla çıktığından, lise öğrenimini tamamlayamayanlar için artık Form-A Belgesi düzenlenemeyecektir. Böylece koruma altında yetişen gençlerin kamuda işe girebilmeleri için 12 yıllık zorunlu eğitimi tamamlamaları gerekecektir. Bu durumda çocuk 18 yaşına gelmiş ve korunma kararı kaldırılmış ancak lise öğrenimini tamamlayamamış ise kurumdan ayrıldıktan sonra lise öğrenimini tamamladığında kurumla iletissime geçecek ve kendisi için Form-A Belgesi düzenlenmesini isteyecektir.

\section{C. Şartı Eğitim Yardımı Programı}

Şartlı Eğitim Yardımı Programı, Aile ve Sosyal Politikalar Bakanlığı Sosyal Yardımlar Genel Müdürlüğü ile Milli Eğitim Bakanlığı koordinasyonunda yürütülen bir programdır. Şartlı Eğitim Yardımı, maddi imkânsızlıklar 
nedeniyle çocuklarını okula gönderemeyen ailelere, çocuklarının okula devam etmeleri şartıyla yapılmaktadır. Ödemeler doğrudan anneler adına açılan hesaplara yapılmaktadır. Kız çocuklarına erkek çocuklarına göre daha fazla yardım yapılmaktadır. 2014 yılında yapılan ödemelere bakıldığında, ilköğretime devam eden erkek öğrenci için aylık 35 TL, ilköğretime devam eden kız öğrenci için aylık 40 TL, ortaöğretime devam eden erkek öğrenci için aylık $50 \mathrm{TL}$, ortaöğretime devam eden kız öğrenci için aylık 60 TL eğitim yardımı ödenmektedir

(http://www.sosyalyardimlar.gov.tr/tr/html/ 11832/Egitim+Yardimlari).

4+4+4 eğitim sistemiyle birlikte şartlı eğitim yardımı programının yeni eğitim sisteminin tanıtılmasının ve yaygınlaştırılmasının bir aracı olarak da kullanılmaya başlandığı söylenebilir. Çünkü Aile ve Sosyal Politikalar Bakanlığının “12 Yıllık Zorunlu Eğitime Yönelik Uygulamalar ve Şartlı Eğitim Yardımı" konulu 2012/23 sayılı Genelgesinde, şartlı eğitim yardımından yararlanacak ailelerin tespit edilmesi aşamasında bu ailelere yeni eğitim sisteminin yararlarının anlatılması, şartlı eğitim yardımından yararlanan ailelere diğer maddi yardımlardan da öncelikli olarak verilmesi gerektiği belirtilmiştir. Diğer yandan çocukların okula devam etmelerini teşvik etmek amacıyla Milli Eğitim Müdürlükleriyle işbirliği halinde şartlı eğitim programının ülke genelinde tanıtımına yönelik yazılı ve görsel faaliyetlerin arttırılması da istenmiştir. Şartlı eğitim yardımına yönelik sorunların çözümü ve soruların cevaplandırılması amacıyla kurum görevlileri okulları ziyaret edecek ve öğretmen, öğrenci, veli ve okul yönetimi ile görüşmeler yapacaktır (ASPB, 2012/23 Sayılı Genelge). Böylelikle maddi imkânsızlıklar içerisinde olan ailelerin zorunlu eğitim süresi sonuna kadar çocuklarını okula göndermeleri teşvik edilmiş olacaktır.

\section{Personelin Sorumluluklar1}

Aile ve Sosyal Politikalar Bakanlığı tarafından 2012/23 sayılı Genelge ile yeni eğitim sistemiyle ilgili olarak personelin ayrıca şu hususlarda gerekli dikkat ve özeni göstermesi istenmiştir:

a) Sosyal inceleme yapmak üzere görevlendirilen personel tarafından gerçekleştirilecek hane ziyaretlerinde, 4+4+4 uygulaması ile okula başlayacak olan 66 aylık çocuklar da dikkate alınacak, okula gitme çağında bulunan başta kız çocukları olmak üzere tüm çocukların tespiti yapılacak, okula gitmesi gereken ancak herhangi bir nedenle okula gönderilmeyen bir çocuk tespit edildiğinde bu durum Milli Eğitim Müdürlüklerine bildirilecektir. 
b) Okul öncesi eğitim çağında bulunan çocukların okul öncesi eğitime devam etmeleri teşvik edilecektir.

c) Sosyo-psikolojik ve sosyo-ekonomik desteğe ihtiyacı oldukları tespit edilenlere söz konusu desteklerin verilmesi sağlanacak ve durumları sürekli izlenecektir. Şartlı eğitim yardımından yararlanan ailelerin diğer maddi yardımlardan da öncelikli olarak yararlanmaları sağlanacaktır.

d) Yeni eğitim sisteminin faydaları ve çocukların iyi yetişmesi ve gelişmesi açısından yararları anne ve babalara anlatılacak ve bu noktada ailelerde bilinç oluşturulması sağlanacaktır.

e) Yapılacak bu çalışmalarla söz konusu tüm çocukların eğitim sistemine katılmaları desteklenecek ve bu çocuklar ilgi, istek ve yetenekleri doğrultusunda yönlendirilecektir.

f) Çocukların okula devam etmelerinin teşvik edilmesi amacıyla Milli Eğitim Müdürlükleri ile irtibat halinde olunacak ve ülke genelinde Şartlı Eğitim Yardım Programının tanıtımına yönelik yazılı ve görsel faaliyetler artırılacaktır.

Diğer yandan ilgili kurum personeli, yaş ve gelişim özelliklerine göre koruma altındaki çocukların okula kayıtlarının yapılmasını ve bu konudaki iş ve işlemlerin takibini sağlayacaktır. Ayrıca koruma altındaki çocuklar da yeni eğitim sistemi hakkında bilgilendirilecek ve bu çocukların eğitim öğretim dönemine hazırlıklı girmeleri sağlanacaktır. Yeni eğitim sistemiyle birlikte ilköğretim sonunda diploma verilmeyeceğinden, 12 yıllık zorunlu eğitim sonunda ortaöğretim diploması alabilmeleri için çocukların tamamının ortaöğretim kurumlarına kayıtlarının yapılması gerekecektir (ASPB, 24/08/2012 tarih ve 1233 sayılı yaz1).

\section{SONUÇ VE TARTIŞMA}

4+4+4 eğitim sistemi Aile ve Sosyal Politikalar Bakanlığında da yeni düzenlemelere neden olmuştur. Aile ve Sosyal Politikalar Bakanlığı tarafından 2012/23 Sayılı Genelge, 24.08.2012 tarihli ve 1233 sayılı yazı ile 28.08.2012 tarihli ve 2581 sayılı yazılarla yeni eğitim sistemine yönelik yapılacak uygulamalar belirtilmiştir. Özellikle çocukların yaş gruplarına ayrılması ve reşit olan çocukların koruma altından ayrılmaları uygulamalarının bu bireylerin yaşamlarını önemli ölçüde etkilediği söylenebilir. Bu uygulamalardan sonra 18 yaş üstü çocukların izlenmesiyle ilgili sorunlar olduğu görülmüş ve bu gençlerin izlenmesi ve topluma kazandırılması yönünden bakanlık ayrıca talimatlar vermiştir. 
4+4+4 eğitim sistemiyle birlikte ASPB kuruluşlarında çocukların yaş gruplarının yeniden belirlenmesinin olumlu bir gelişme olduğu söylenebilir. 06 yaş kuruluşların 0-5 yaş şeklinde, $7-12$ yaş kuruluşların 6-9 yaş ve 10-13 yaş şeklinde, 13-18 yaş kuruluşların ise $14-15$ yaş ve 16-18 yaş şeklinde yapılandırılması ile birbirine daha yakın yaş gruplarının bir arada olması ve böylelikle yaş farkı fazla olan çocukların birbirlerine olumsuz davranışta bulunmalarının engellenmesi sağlanmaya çalışılmıştır. Ancak uygulamada bu şekilde bir yapılanmanın yeterince sağlandığını söylemek zordur. Bu şekilde yapılanmayı karşılayacak yeterli sayıda bina ya da kuruluş bulunamadığından çocukların daha çok çocuk evlerine yerleşmeleri sağlanarak benzer yaş gruplarının bir arada olması sağlanmaya çalışılmıştır. Burada önemli olan bir nokta da, 10-13, 14-15 ve 16-18 yaş grupları bir arada olacak şekilde müstakil kuruluş yapılanması pek mümkün olmadığından, önceden ilkokul beşinci sınıfı bitirip yetiştirme yurduna gelen bir çocuk 18 yaşa kadar büyük yaş grubu çocuklarla bir arada kalıyorken yeni durumda ilkokul dördüncü sınıfı bitiren bir çocuğun büyük yaş grubundaki çocuklarla bir arada kalması gibi bir durum ortaya çıkmıştır. Çocuk evleri ve koruyucu aile sayısındaki artışlarla farklı yaş grubu çocukların bir arada kalması engellenmeye çalışılmaktadır.

4+4+4 eğitim sistemiyle birlikte zorunlu eğitimin 12 yıla çıkması, koruma altındaki çocukların kuruluşlardan ayrılışını da etkilemiştir. Daha önce ilköğretimi tamamlayınca kamu kurum ve kuruluşlarında işe yerleşebilmek için gerekli Form-A Belgesi doldurulabiliyorken, yeni eğitim sisteminden sonra lise öğrenimini tamamlayan çocuklara Form-A Belgesi düzenlenmeye başlamıştır. Ancak Bakanlık yaptığı son düzenlemelerle ilkokul ve ilköğretim mezunu olanlara tekrar Form-A Belgesi düzenlemeye başlamıştır. Ancak ilkokul ve ilköğretim/ortaokul mezunu olanlar kamuda yardımcı hizmetler sınıfında (hizmetli) istihdam edilebilmektedir. Koruma altından ayrilan gençlerin kamuda memur ve üstü hizmetlerde istihdam istihdam edilebilmeleri için bir şekilde 12 yıllık zorunlu eğitimi tamamlamaları önemlidir.

Normal olarak çocukların koruma kararları 18 yaşına geldiklerinde kaldırıldığından, lise öğrenimini tamamlayamadan kurumdan ayrılanların öğrenimlerini tamamlayabilmeleri ve işe yerleşebilmeleri için ayrıca desteklenmeleri ve kendilerine rehberlik edilmesi gerekmektedir. Reşit olup kurumdan ayrıldıktan sonra ailesi veya herhangi bir yakını yanına dönmeyen ya da dönemeyen gençlerin örgün eğitimle liseyi bitirmeleri daha zor olabilir. $\mathrm{Bu}$ durumda bu gençlerin açık lise öğrenimiyle zorunlu eğitimi 
tamamlayabilmeleri için ayrıca desteklenmeleri gereklidir. Zorunlu eğitimi tamamladiktan sonra kendilerine tanınan istihdam hakkında yararlanabilmeleri içinse bu gençlerin kurumla irtibatlarını sürdürmeleri konusunda gerekli işbirliği ve iletişim sağlanmalıdır. Şartlı eğitim yardımı programını etkin bir şekilde kullanarak tüm çocukların zorunlu eğitime devam etmelerini desteklemeyi amaçlayan ASPB'nin, koruma altındaki çocukların zorunlu eğitimlerini tamamlayabilmeleri için de bazı tedbirler alması gereklidir. Bu konuda öncelikle çocuklar 18 yaşında reşit olduğunda kuruluştan ayrılmaları idarelerin kanaatine bırakılmadan bu çocukların koruma kararları 20 yaşına kadar uzatılmalıdır.

Her ne kadar ASPB ilgili genelge ve yazılarla kurum personeline yeni eğitim sistemi konusunda ailelerde bilinç oluşturulması, yeni eğitim sisteminin tanıtılması ve çocukların uygun okullara yönlendirilmesi gibi görevler vermiş olsa da öncelikle kurum personelinin bu konuda bilgilendirilmesi ve İl Milli Eğitim Müdürlükleriyle yeterli düzeyde işbirliği yapılması gereklidir.

\section{KAYNAKÇA}

AİLE VE SOSYAL POLİTIKALAR BAKANLIĞI. (ASPB). (2012). 2013-2017 Stratejik Plan1. Ankara: ASPB Yayını.

AİLE VE SOSYAL POLİTIKALAR BAKANLIĞI. 12 Yıllık Zorunlu Eğitime Yönelik Uygulamalar ve Şartlı Eğitim Yardımı Konulu 2012/23 Sayılı Genelge.

AİLE VE SOSYAL POLİTİKALAR BAKANLIĞININ TESSKILLAT VE GÖREVLERİ HAKKINDA 633 SAYILI KANUN HÜKMÜNDE KARARNAME. 08.06.2011 tarihli ve 27958 sayll Resmi Gazete.

SOSYAL HIZMETLER KANUNU. 27.05.1983 tarihli ve 18059 sayll Resmi Gazete.

AİLE VE SOSYAL POLİTIKKALAR BAKANLIĞI. 12 Yıllık Zorunlu Eğitime Yönelik Uygulamalar konulu 24.08.2012 tarihli ve 1233 sayıll yazı.

AİLE VE SOSYAL POLİTİKALAR BAKANLIĞI. 12 Yıllık Zorunlu Eğitim Kapsamında Kuruluşların Yapılandırılması konulu 28.08.2012 tarihli ve 2581 sayılı yazı.

ÇELIK, Z., BOZ, N., GÜMÜŞ, S. VE TAŞTAN, F. (Tarihsiz). 4+4+4 Eğitim Reformunu İzleme Raporu. Ankara: Eğitim- Bir-Sen Yayını.

ÇOCUK HIZMETLERI GENEL MÜDÜRLÜĞÜ. (2014). May1s 2014 İstatistikleri. Web: http://www.cocukhizmetleri.gov.tr/upload/Node/10542/files/Mayis.pdf (14.09.2014)

EĞİTì-İŞ. (2012). 2012-2013 Eğitim-Öğretim Yılı 4+4+4 Zorunlu Eğitim Yasasıyla Başlıyor. Ankara: Eğitim-İş.

EĞİTiM REFORMU Gİișìì. (Tarihsiz). 4+4+4'e Geçiş: Eylül 2012 Bilgi ve Politika Notlar. İstanbul: Eğitim Reformu Girişimi.

MİLLİ EĞİTiM BAKANLIĞI. (2012). 12 Yıl Zorunlu Eğitim Sorular Cevaplar. Ankara: MEB.

MİLLİ EĞİTìM BAKANLIĞI. Özel Eğitim Hizmetleri konulu 16/08/2012 tarihli ve 3284 sayıl1 yazı.

Web: $\quad$ http://www.sosyalyardimlar.gov.tr/tr/html/11832/Egitim+Yardimlari (14.09.2014). 